\title{
EL PÍCARO Y LA VOZ: REFLEXIONES SOBRE LA PRÉDICA Y LA MURMURACIÓN EN EL GUZMÁN DE ALFARACHE
}

\author{
FRANCISCO RAMíREZ SANTACRUZ \\ Benemérita Universidad Autónoma de Puebla
}

Si bien cuando Mateo Alemán publica la Primera Parte del Guzmán en 1599 cada vez era menor el número de lectores en voz alta, dicha práctica tardó aún muchos decenios en ceder paso a la lectura silenciosa. El lenguaje del libro de Alemán es un testimonio vocal de que los lectores de antaño modulaban la voz y gesticulaban mientras leían. Esto, por supuesto, no implica que el Guzmán haya sido concebido para ser leído en su totalidad en voz alta; más bien, lo que sugiere es un espacio de resonancias y de transición entre la letra y la voz, donde se generan diversos tonos de lectura que

1 El presente estudio es una versión modificada de la ponencia «La oralidad en el Guzmán de Alfarache» presentada en el coloquio internacional «La picaresca española y sus proyecciones europeas - un género en debate», organizado por Katharina Niemeyer y Pedro Piñero en Colonia, los días 22-25 de mayo de 2008. 
pueden verbalizarse o no. ${ }^{2}$ Seguramente más de un lector del XVII se preguntó cómo era la voz de aquel galeote parlero, conocedor profundo de las necesidades humanas y curtido en los más bajos fondos sociales, y con su lectura en voz alta dio solución a muchas de las ambigüedades del texto que suelen ser herméticas para el moderno lector afásico. La pertinencia de la cuestión se torna aún más ineludible si se repara que el pícaro vive y muere por la palabra hablada. ${ }^{3}$ El protagonista es un hombre de una facundia portentosa, quien en muchas ocasiones le debe más su buena fortuna a su prodigioso ingenio verbal que a sus sagaces engaños. Los personajes que interactúan con él son continuamente seducidos por su capacidad de hablarles al oído y ganárselos para sus oscuras intenciones; el lector, a su vez, percibe en el narrador una instancia con dominio envidiable de cualquier género discursivo, así como de sus respectivos tonos que ostentan un margen tan distante entre sí como el que va de la prédica moral hasta la murmuración. Dicho de otra manera, en la España descrita por Mateo Alemán, le es dado a un galeote de dudosa calidad moral ser el mejor orador de su tiempo.

Diversos críticos han reconocido la orientación oral de la prosa alemaniana así como la importancia del tono para alcanzar eficazmente la verosimilitud, pero no se ha indagado aún de manera precisa qué tipo de voces sociales resuenan subrepticiamente en el Guzmán; para ello debemos aguzar los oídos y escuchar el gran universo sonoro

2 Recuérdese el ventero del capítulo 32 del Quijote de 1605: «Porque cuando es tiempo de la siega, se recogen aquí las fiestas muchos segadores, y siempre hay algunos que saben leer, el cual coge uno destos libros en las manos, y rodeámonos dél más de treinta y estámosle escuchando con tanto gusto, que nos quita mil canas» (Miguel Cervantes, Don Quijote de la Mancha, ed. de Francisco Rico, Barcelona, Crítica, 1998, p. 369). Para una exposición de la práctica de la lectura en los siglos de oro, véase Margit Frenk, Entre la voz y el silencio. La lectura en tiempos de Cervantes, México, Fondo de Cultura Económica, 2005.

3 G. Sobejano, al estudiar en las obras picarescas lo que él llama la forma generadora del modo de usar el lenguaje, sostiene: «el pícaro habla mucho, y habla -con típica frecuencia- para censurar las acciones ajenas y aun las propias; locuacidad, pues, y crítica, o sea: locuacidad crítica» («Un perfil de la picaresca: el pícaro hablador», en Studia Hispanica in Honorem R. Lapesa III, Madrid, Gredos, 1972, p. 467; cursivas del autor). Sabemos, gracias a la Ortografía castellana (1609), que Alemán le otorgaba un lugar privilegiado a la voz humana: «Y así, no hay duda, que la voz de todo buen orador son colores que realzan y levantan de punto el dibujo de la pluma, con que tácitamente llevamos ya confesado por la parte contraria nuestro propósito. [...] La voz hace fuerza, compele y obliga sin tener quien le resista [...]» (ed. de J. Rojas Garcidueñas, estudio preliminar de Tomás Navarro, México, El Colegio de México, 1950, pp. 119 y 121; modernizo la ortografía).

4 G. C. Peale fue de los primeros estudioso en advertir que «La presencia innata del gesto y del acento es tal vez la prueba última de la orientación oral de la prosa de Mateo Alemán. [...] En el Guzmán de Alfarache, el lenguaje suple al habla, con todos sus equívocos y vaguedades que sólo el gesto y la inflexión pueden precisar a su modo tan eficaz» («Guzmán de Alfarache como discurso oral», Journal of Hispanic Philology, 4 (1979), pp. 49 y 51). El tono en el Guzmán, por otra parte, es decisivo en la estrategia de legitimación del protagonista así cómo para alcanzar la empatía de su lector, según observa Cavillac: «[...] dentro del dialogismo estructural que informa la Atalaya, no es aventurado acotar un espacio de diálogo específico entre el narrador y un alocutario lo bastante personalizado (en cuanto receptor comprometido con la ficción) para no ser confundido con el tú indefinido del didactismo moral que abarca a todos los lectores. La relevancia de dicha interacción dialogal (implícita o explícita) confiere al texto un potente efecto de verosimilitud al teñir de oralidad la escritura del Guzmán en una época 
que se esconde tras la pluma de Alemán. ${ }^{5}$ La reconstrucción oral de la partitura del Guzmán -obra cuya estructura narrativa debe mucho a la retórica clásica según varios eruditos- ${ }^{6}$ en principio pasaría por la elección apropiada de los códigos retóricos cultos y de su acertada ejecución. Lo más lógico sería acudir, en primer lugar, a los estudios clásicos sobre la voz en algunas obras de Cicerón, las Instituciones oratorias de Quintiliano o la Retórica a Herenio; en ellas encontramos preceptos sobre cómo debía entonar el orador las distintas secciones de su discurso e incluso se distinguen las tres cualidades más importantes de la voz: volumen, firmeza y flexibilidad. En segunda instancia se podría recurrir a los manuales de oratoria sagrada de los siglos XVI y XVII, que, en lo general, fueron concebidos a partir de los tratados de marras. Ahora bien, tanto los autores clásicos como los manuales de retórica eclesiástica sostienen que el predicador o el orador debe ser un hombre íntegro y enseñar con el ejemplo ${ }^{7} \mathrm{y}$, aunque Guzmán emplea diversas estrategias de legitimación, lo cierto es que en el lector subsiste la impresión de que el pícaro no está moralmente calificado para discurrir sobre la virtuosa vida cristiana. Vale advertir que dicha mácula moral no lo es desde el punto de vista estético, pues se trata de una de las características que subrayan la naturaleza moderna del texto y podemos resumir bajo el concepto de ambigüedad, ${ }^{8}$ al grado de que Hilary D. Smith concluye que los sermones del pícaro se aproximan sospechosamente a la murmuración. ${ }^{9}$ La misma estudiosa subraya la condición

en que era común la lectura en voz alta» («El diálogo del narrador con el narratario en el Guzmán de Alfarache de Mateo Alemán», Criticón, 101 (2001), p. 328). Recientemente Ph. Rabaté ha postulado, al estudiar las huellas de la doctrina agustiniana en la obra y su impronta en el estilo, que «Las voces del Guzmán entrarían así en resonancia con la oralidad de varios textos agustinianos, entre ellos los diálogos y, sobre todo, los soliloquios» («El discurso agustiniano de Mateo Alemán: de la herencia adánica a la “reformación" individual en el Guzmán de Alfarache», Criticón, 107 (2009), p. 130).

5 En la Ortografía castellana sostiene nuestro autor que su propósito principal es "que a la lengua imite la pluma" (op. cit., p. 34).

6 Véanse E. Cros, Protée et le gueux. Recherches sur les origines et la nature du récit picaresque dans «Guzmán de Alfarache», París, Didier, 1967 ; del mismo autor, Mateo Alemán. Introducción a su vida y obra, Salamanca, Anaya, 1971, pp. 75-93; y L. López Grigera, «La invención del Guzmán de Alfarache (1599) entre Poética y Retórica», en P. M Piñero Ramírez (ed.), Atalayas del «Guzmán de Alfarache». Seminario internacional sobre Mateo Alemán. IV Centenario de la publicación de Guzmán de Alfarache (1599-1999). Sevilla, Universidad de Sevilla, 2002, pp. 255-270.

7 Fray Diego de la Vega en su Empleo y ejercicio sancto sobre los evangelios de las dominicas de todo el año de 1604 opina: «De tal manera había de vivir un predicador, que cuando le viesen ir por la calle, dijessen: "Véis allí el sermón puesto por obra"». Y B. Ximénez Patón, en su Elocuencia española en arte (Toledo, 1604) insiste: «[...] en nuestros tiempos el predicador es el orador, y así en él son los requisitos que pone Cicerón en su perfecto orador» (citado por H. D. Smith, «The Pícaro Turns Preacher: Guzmán de Alfarache's Missed Vocation», Forum for Modern Language Studies, 14 (1978), pp. 392 y 396).

8 Véanse N. von Prellwitz, Il discorso brifonte di Guzmán de Alfarache Roma, Bagatto Libri, 1992; y F. Márquez Villanueva, «La interacción Alemán-Cervantes» en Trabajos y días cervantinos, Alcalá de Henares, Centro de Estudios Cervantinos, 1995, pp. 252-253.

9 "Often, it is true, the sermons of Guzmán sound suspiciously like murmuración, although it is a vice, allied to that of judging by appearances, that he is quick to discern and condemn in others" (H. D. Smith, op. cit., p. 393). 
ambivalente del subtítulo de la Segunda Parte, Atalaya de la vida humana, pues si bien alude a la imagen de Hércules en el emblema de Alciati, donde representa la elocuencia $\mathrm{y}$, por extensión, al predicador, también hace referencia al sitio desde donde ciertas aves de rapiña acechan a sus víctimas. ${ }^{10}$ Refuerza esta connotación negativa el hecho de que «atalaya» signifique en germanía 'ladrón' ${ }^{11}$ Ahora bien, para los españoles de aquella época la cadena semántica atalaya-predicador-ladrón podía incluir también al murmurador, según registra Fray Diego de la Vega: «Los murmuradores son de ordinario las atalayas del pueblo, traen hechos centinelas los ojos, notando lo que pasa [...] para ir cebando el fuego que en sus lenguas encienden». ${ }^{12}$ Ante este hecho se resquebraja la correcta aplicación del arte de la elocuencia para identificar los tonos de la Atalaya, pues de un orador o predicador inmoral e imperfecto o de un sermón que se entone murmurando no hay actio registrada en las retóricas clásicas ni entre los brillantes preceptistas de la retórica eclesiástica como fray Luis de Granada, fray Diego Murillo o Francisco Terrones del Caño. Por consiguiente, sin la reconstrucción de dicha actio no estamos en condiciones para hacer una correcta identificación y ejecución de uno de los tonos predominantes -el de la murmuración- en el Guzmán.

El tono de marras deriva de un arte vocal o de una técnica articulatoria inventada en La Celestina, que, primero, rescató el anónimo autor del Lazarillo y, después, elevó a proporciones épicas Mateo Alemán con su oído finísimo. ${ }^{13}$ A la segunda versión de la Comedia, Fernando de Rojas añadió una serie de paratextos, de los cuales destacan para nuestro argumento las octavas de Alonso de Proaza («Dize el modo que se ha de tener

10 Atestiguan esta acepción los versos de la estrofa 270 Libro de buen amor: "El águila cabdal cata sobre la faya, / todas las otras aves de allí las atalaya; / non ay péndola d'ella que en [la] tierra caya; / si vallestero la falla, préçiala más que saya" (Arcipreste de Hita, Libro de buen amor, ed. de A. Blecua, Madrid, Cátedra, 1998).

11 Diccionario de Autoridades, 3 vols., ed. facsímil, Madrid, Gredos, 1990.

12 Citado por H. D. Smith, op. cit., p. 394.

13 Obsérvese la gran capacidad auditiva de Alemán que se infiere de la Ortografía castellana: "La $x$ y la $j$ tienen cierta manera de similitud o parentesco, según la $s$ con la ç, por donde algunos las truecan, diziendo dixe por dije, no advirtiendo que la $x$ es más tenue, y se pronuncia casi como el silvo, la lengua poco menos que junta con el paladar; y para la $j$, se tiene de retirar, y fórmase por entre dientes, con solo el aliento" (op. cit., p. 108). Los trabajos de G. Illades sobre la técnica articulatoria de "hablar entre dientes" en La Celestina, en el Quijote y en un conjunto de obras menos canónicas han sido la inspiración para indagar el arte vocal del Guzmán. De sus espléndidos artículos, pioneros y seminales en más de un sentido, me sirvo ampliamente para desarrollar el presente trabajo, así como para exponer cómo dicha técnica nace con La Celestina y no es estudiada por ningún rétor clásico. Coincido con Illades en algunas de las conclusiones que obtiene del estudio del arte de mal decir para la novela picaresca. Finalmente, aclaro que ante la imposibilidad de citarlo a cada página he preferido dejar aquí constancia de mi enorme deuda con sus investigaciones. De su extensa bibliografía destaco, para los fines de este estudio, tres artículos: «Observaciones sobre la actio del lector. (De La Celestina a la sátira anónima novohispana)», Escritos, Revista del Centro de Ciencias del Lenguaje, 26 (2002), pp. 13-35; «Arte y pecado de mal decir en el Quijote de 1605», en G. Illades y J. Iffland (eds.), El "Quijote» desde América, México, Benemérita Universidad Autónoma de Puebla-El Colegio de México, 2006, pp. 163-182; «Sátira, prédica y murmuración: genealogía de una contienda por la voz en el Quijote de 1605», Cervantes, 27.1 (2007), pp. 161-178. 
leyendo esta comedia»). Las octavas contienen una miscelánea de instrucciones para leer en voz alta la historia de Calisto y Melibea: «Si amas y quieres a mucha atención / leyendo a Calisto mover los oyentes, / cumple que sepas hablar entre dientes, / a veces con gozo, esperanza y pasión. / A vezes ayrado, con gran turbación. / Finge leyendo mill artes y modos, / pregunta y responde por boca de todos, / llorando y riendo en tiempo y sazón». ${ }^{14}$ El consejo más enigmático y sobresaliente se refiere a la técnica de «hablar entre dientes». Dicha práctica -enfocada a provocar atención y conmoción («mover los afectos», dirían algunos rétores)- fue desconocida por la retórica clásica, empero, sin la destreza para «hablar entre dientes» el lector único de La Celestina no sabría cómo pronunciar los constantes apartes de la obra. Tampoco las comedias de Terencio y Plauto, influencia importante en la obra de 1499, permiten extraer una técnica para enunciar sus numerosos apartes. Por ende, se puede asumir que con $L a$ Celestina se introduce el aparte en la literatura española y que su editor, Proaza, fue el primero en proponer una actio del «hablar entre dientes».

Según Sebastián de Covarrubias, se dice murmurar «el decir mal de otro hablando entre dientes». La unidad fraseológica «hablar entre dientes» en su acepción de 'murmurar' o de 'hablar para sí está documentada desde el Libro de Alexandre y el Arcipreste de Hita. ${ }^{15}$ De su lado, el Diccionario de Autoridades apunta bajo el lema «diente»: «Hablar ù decir entre dientes. f. Hablar quedo, confuso y sin formar bien las palabras; las mas veces significa murmurar, gruñir, ò refunfuñar por lo que se manda ù dice». ${ }^{16}$ De regreso a Covarrubias observamos que el toledano define «murmuración» como «plática nacida de embidia, que procura manchar y obscurecer la vida y virtud ajena (...) y es oficio de gente vil y baxa a quien ninguna vianda sabe bien si no le tocan en vida agena. San Bernardo [...] dize que la lengua maldiciente y murmuradora es pinzel del demonio y semejante a la víbora». ${ }^{17}$ «Hablar entre dientes» $\mathrm{O}$ «murmurar»

14 F. de Rojas, Comedia o Tragicomedia de Calisto y Melibea, ed. de P. E. Russell, Madrid, Castalia, 1991, pp. 613-614.

15 Libro de Alexandre, estrofa 13: «Los unos con los otros fablavan entre dientes: / "Est niño conquerrá las indïanas gentes". / Phelipo e Olimpias, que eran sus parientes, avián grant alegría, metién en todo mientes» (Libro de Alexandre, ed. de J. Cañas, Madrid, Cátedra, 1995). Libro de buen amor, estrofa 373: «A obra de piedad tú nunca paras mientes, / nin visitas los presos nin quieres ver dolientes, / sinon solteros sanos, mançebos e valientes; / si loçanas encuentras, fáblasles entre dientes»; y estrofa 487: «Diz la muger entre dientes: “Otro Pedro es aquéste, / más garçón e más ardit qu'el primero que ameste: / el primero apost d'éste non vale más que un feste, / con aquéste e por éste faré yo, sí Dios me preste"» (Arcipreste de Hita, op. cit.).

16 Cabe advertir que la expresión no fue desconocida para nuestro autor; en la novela intercalada de «Ozmín y Daraja» se lee: «Así Ozmín poco a poco, con cuidadoso descuido se fue paseando por delante, cantando en tono bajo, como entre dientes, una canción arábiga, que para quien sabía la lengua eran los acentos claros, y para la que no y estaba descuidada, le parecía el cantar de lala, lala...». (I, p. 250; se cita según la edición de J. M. Micó, 2 tomos, Madrid, Cátedra, 1992 y 1994).

${ }_{17}$ Tesoro de la lengua castellana o española, ed. de M. de Riquer, Barcelona, Alta Fulla, 2003. La definición del eminente lexicógrafo parece ser una cita textual del Guzmán, lo cual sugiere que Covarrubias veía en Alemán a una autoridad en el tema: «La mormuración, como hija natural del odio y de la invidia, 
poseía, entonces, sinónimos en envidiar, maldecir, farfullar y, en algunos casos, en dar voz al demonio. Antes que Covarrubias, Mateo Alemán ya había sugerido en su San Antonio de Padua (1604) que el mayor daño que viene a los hombres lo ocasiona la lengua a quien tilda de «dañoso loco» ${ }^{18}$ y no había titubeado en asociar la murmuración -para múltiples moralistas un pecado de la lengua- al demonio, cuando arremetió contra aquellos murmuradores que sostienen que la verdad es hija de Dios y, por consiguiente, la divulgan sin miramientos:

Mal sientes de la verdad, porque tú no eres el juez o censor de las insolencias, ni esa tu verdad es hija de Dios, antes tuya, y ella y tú sois hijos del demonio: porque, cuando la honra de tu prójimo corre de por medio, no se debe decir palabra con que se ofenda, ni puedes afrentarlo con ella, presente ni ausente, ni derribar un grano de mostaza de la opinión en que lo tienen otros: y si eres amigo de verdades, di de ti, como dices de otro, descubre tus defetos, como en pregón publicas los ajenos. ${ }^{19}$

Ahora bien, el Guzmán luce como un tratado o compendio en torno a la murmuración y sus múltiples variantes; el acto de murmurar es omnipresente e incesante. Todo el tiempo se murmura, se responde a la murmuración ajena o se reflexiona sobre las repercusiones de esta mordaz práctica social. ${ }^{20} \mathrm{El}$ pícaro sevillano, antes que a cualquier otra cosa, le teme a las habladurías. ${ }^{21}$ Inexorablemente el lector termina por tener la impresión de que Alemán identifica en el mal decir una pandemia de su tiempo, que atenta contra la estabilidad social. ${ }^{22}$

siempre anda procurando cómo manchar y oscurecer las vidas y virtudes ajenas. Y así en la gente de condición vil y baja, que es donde hace sus audiencias, es la salsa de mayor apetito, sin quien alguna vianda no tiene buen gusto ni está sazonada» (I, p. 224). Tampoco cabe desechar la hipótesis de que ambos autores partan de una fuente común, que no he podido identificar.

18 San Antonio de Padua, Sevilla, Clemente Hidalgo, 1604, f. 88v.

19 Ibidem, f. 120v.; modernizo la ortografía. Pese a estas consideraciones, Guzmán está muy lejos de atenerse a esta doctrina. Un buen panorama sobre cómo los moralistas valoraban la murmuración la ofrece, C. Chauchadis, «Virtudes y pecados de la lengua: Sebastián de Covarrubias y Martín de Azpilcueta», Criticón, 92 (2004), pp. 39-45.

20 « $\mathrm{Oh}$, esto de los corrillos y murmuraciones, y cómo es larga historia! ¡Quién tuviera lugar de significar [...]» (I, pp. 415-416). «Son los murmuradores como los ladrones y fulleros. [...] El fullero ladrón hurta, porque con aquello pasa; como no lo tiene, trata de quitarlo a otros, dondequiera que lo halla. Desta manera, el noble tiene para sí la honra que ha menester y aun para poder honrar a otros, y el murmurador se sustenta de la honra de su conocido, quitándole y desquilatándole della cuanto puede, porque le parece que, si no lo hurta de otros, no tiene de dónde haberlo para sí» (II, pp. 261-262).

${ }^{21}$ «¿Cómo trataré de linajes, para encajar la limpieza del mío? ¿Cómo descubriré al otro su falta, para quien oyere que la murmuro piense que yo no la tengo? ¿Cómo tendré conversación, para hacer ostentación? ¿Por dónde rodearé, para encajar mi dicho? ¿A qué corrillos iré, que yo sea el gallo y en saliendo dellos no me murmuren, como hice de los otros?» (I, p. 415).

$22 \mathrm{Ni}$ el protagonista ni quienes le rodean escapan de dicha enfermedad: «En lo que me pude adelantar no me detuvo la pereza; no di lugar que de mí se diesen quejas verdaderas ni me trajeran en revueltas. Huí de los deste trato y más de chismosos, a quien con gran propiedad llaman esponjas: aquí chupan lo que allí esprimen. De los tales no se fíen, apártense dellos, aborrezcan su compañía, aunque en ella se interese, porque al cabo ha de salirse con pérdida y descalabrado. No puede una casa padecer mayor calamidad ni la república más contagiosa pestilencia, que tener hombres cizañeros y revoltosos, amigos 
A nivel lingüístico, el vocabulario de la murmuración es pingüe y afecta otros campos lexicográficos. Entre los sinónimos de «murmurar» se hallan, entre otros, «morder» (I, p. 109), «redargüir» (I, p. 125), «desenterrar» (I, p. 126), «enmascarar» (I, p. 129), «aniquilar» (I, p. 129), «infamar» (I, p. 131), «manchar» (I, p. 224), «escurecer» (I, p. 224), «espulgar», «censurar» (I, p. 411) y «gruñir» (I, p. 434). Ciertas unidades fraseológicas son en verdad ingeniosas, pues patentizan el talento del autor para conseguir interferencias entre el campo semántico de la murmuración y los de la medicina, la costura, las leyes y otros. Brindo algunos ejemplos: «cortar de tijera» (I, p. 126), «hacer glosas» (I, p. 127), «multiplicar con los ceros de su antojo» (I, p. 127), «herir las honras» (I, p. 130), «abrasar las famas» (I, p. 130), «pasar la palabra de mano en mano» (I, p. 224), «hablar en corrillos» (I, p. 309), «fiscalizar a otros» (I, p. 459), «espulgar la mota en el ojo ajeno»y «ventear flaquezas ajenas» (II, p. 54). «Chismes» (I, p. 459), «mala voz» (I, p. 139) y «revueltas» (I, p. 309) son expresiones intercambiables por la de «murmuración» y el difamador es descrito como «lenguaz» (I, p. 295), «deslenguado» (II, p. 184)), «malsín» (I, p. 194), «almotacén» (I, p. 416), «perro» (II, p. 54), «ladrón» o «fullero» (II, p. 261), mientras que a la masa anónima que chismorrea se le pinta como «maldicientes» (I, p. 132), «cizañeros» $\mathrm{O}$ «revoltosos» (I, p. 309).

Desde la perspectiva estructural y de la configuración del personaje la maledicencia pone su sello a tres momentos axiales de la obra, pues a duras penas se capta el tono del seminal primer capítulo, de la acción de encomendarse a «Dios y buenas gentes» $(\mathrm{I}, \mathrm{i}, 2)$ antes de salir a ver mundo y del capítulo final sin tener en cuenta la actio de la murmuración y sus consecuencias éticas. Contrarrestar las calumnias contra su progenitor es el objetivo primordial de Guzmán en el inicio. Los chismes son enunciados por una voz colectiva, que se oculta bajo el lacónico «se dice». Las primeras cuatro oraciones de la novela contienen sinónimos del verbo «murmurar» o expresiones afines a su campo semántico. El incipit da la pauta a seguir: el narrador confiesa su temor por no atenerse a la preceptiva para contar su historia y recela que se le «redarguya de pecado» (I, p. 125), al no proceder de la definición a lo definido. «Redargüir», anota Covarrubias, «algunas veces vale calumniar». ${ }^{23}$ De inmediato el pícaro advierte que sólo relatará lo fundamental, «dejando lo que no me es lícito, para que otro haga la baza» (I, p. 126). La frase «no dejar hacer baza», tomada del juego de naipes, vale metafóricamente «lo mismo que hablar mucho, y de modo que no

de hablar en corrillos y hacerlos» (I, p. 309). Por otra parte, el capitán, uno de los primeros amos de Guzmán, se deleita murmurando, así también el embajador, patrón de Guzmán en la Segunda Parte: «Estuvimos en la conversación [el capitán y yo] buen rato. Y, si va a decir verdades, murmuramos de la corta mano de los hombres valerosos y cuán abatida estaba la milicia [...]» (I, p. 360); «Eran personas principales: uno capitán, el otro letrado; pero para él enfadosísimos y cansados ambos y de quien antes había murmurado comigo a solas» (II, p. 82).

${ }^{23}$ Para el mismo lexicógrafo argüir a uno de pecado significa «levantarle algún falso testimonio, torciendo en mal sentido lo que se ha hecho o dicho». 
deja hablar a otro, ni decir su razón»(Autoridades). Guzmán, entonces, abre la puerta a la posibilidad de que la gente hable mal de sus padres. La tercera oración da pie a una nueva variante del cuchicheo cuando el galeote advierte que no es bueno andar «desenterrando cuerpos muertos», cuyo sentido figurado equivale a «murmurar»y, finalmente, subraya que él no les «cortara de tijera» a sus progenitores, aunque así parezca. «Cortar de tijera» de nueva cuenta corresponde a «chismorrear». «Redargüir de pecado», «desenterrar cuerpos muertos»y «cortar de tijera» son tres lexemas, extraídos de distintos campos semánticos, que comienzan a tejer la extensa red verbal de la maledicencia compuesta de sinónimos, asociaciones y frases hechas. A su vez, las imágenes que proyectan dichos lexemas evidencian no sólo sus terribles consecuencias, sino el insoportable miedo que padece el protagonista. ${ }^{24}$

Siguiendo con el capítulo inicial, vemos cómo la vida de los padres está sujeta a un constante chismorreo («fue su vida tan sabida y todo a todos tan manifiesto», [I, p. 127]) y que el hijo no posee los argumentos necesarios para refutar lo que está a ojos vistas, pues sería echar más leña al fuego («dar nueva materia de murmuración», [I, p. 127]). A continuación, el narrador interrumpe su relato familiar para dar paso a una breve anécdota, cuya reflexión final ilustra la fenomenología de la murmuración:

Común y general costumbre ha sido y es de los hombres, cuando les pedís reciten o refieran lo que oyeron o vieron, o que os digan la verdad y sustancia de una cosa, enmascararla y afeitarla, que se desconoce, como el rostro de la fea. Cada uno le da sus matices y sentidos, ya para exagerar, incitar, aniquilar o divertir, según su pasión le dita. Así la estira con los dientes para que alcance; la lima y pule para que entalle, levantando de punto lo que se les antoja [...] ni dicen la cosa si no la comentan como más viene a cuento a cada uno (I, p. 129).

Según se colige, la comidilla es hija de seres anónimos identificados sólo por la fuerza de sus dientes que exageran, incitan o aniquilan, es decir, murmuran. ${ }^{25}$

24 Véanse A. J. Cascardi, «The Rethoric of Defense in the Guzmán de Alfarache», Neophilologus 63 (1979), pp. 380-399; y J. Arias, Guzmán de Alfarache: The Unrepentant Narrator, Londres, Tamesis, 1977, pp. 18-20.

25 La imagen canina estaba muy en boga entre los moralistas para describir a esta clase de gente; así el franciscano Fray Diego de la Vega sentencia en su Empleo y exercicio sancto sobre los evangelios... de 1604 que «el hombre que es fácil en murmurar y decir mal de su próximo [...] es semejante al perro que llevaba atravessado por el muslo alguna saeta» (en H. D. Smith, op. cit., p. 393). La misma crítica recuerda que la figura del perro es ambigua, pues si bien el predicador podía ser visto como un perro que pastorea el rebaño, también se asemeja a los cínicos, que, como el pícaro, ocupan un lugar poco privilegiado: «Cervantes plays on this ambiguity in El coloquio de los perros, a work with a strong flavour of the picaresque, in which the dog Berganza, who is telling his life-story, moralizes like a preacher about his adventures as the canine equivalente of a mozo de muchos amos. The masters themselves are the rascals, not the picaro, and yet in companion Cipión reminds Berganza that his "preaching" comes dangerously close to murmuración or malicious fault-finding: indeed, it is a characteristic of dogs to be interested in excrement, their own and that of others» (op. cit., p. 392). Sobra decir que el mismo Guzmán se atribuye atributos perrunos cuando habla de su relación íntima con una esclava: «No sé cómo nos olimos, que tan en breve nos conocimos» (II, p. 477). F. Márquez Villanueva sostiene que Berganza y Alemán comparten un origen sevillano, la tendencia a murmurar y un judaísmo, lo cual convierte al primero en un Mateo Alemán «de cuatro patas»: «Semejante llamada a juicio del escritor 
El resto del capítulo depara la airada defensa de Guzmán de su padre, así como la condena de quienes han murmurado sobre él, ya infamándolo por sus sospechosas prácticas religiosas, ya por ser un renegado o por rumores en torno a su orientación sexual. A estos habladores, el narrador llama «lenguas engañosas y falsas que, como saetas agudas y brasas encendidas, les han querido herir las honras y abrasar las famas» (I, p. 130). Es preciso insistir en la saturación verbal en torno a este tema. Desde todos los frentes acomete la voz colectiva la reputación paterna: «lo que algunos dicen» (I, p. 131), «y digan si haya sido» (I, p. 132), «dirán lo que muchas veces con impertinencia y sin propósito me dijeron» (I, p. 133), «Alguno del arte mercante me dirá» (I, p. 134), «que estuvo preso por lo que tú dices o a ti te dijeron» (I, p. 134) o "por ahí dicen algunos» (I, p. 137). Las palabras «murmurar», «murmuración»o «murmurador» colman el inicio de la novela. ${ }^{26}$ Finalmente, la terminología de la maledicencia es complementada por los lexemas «oprobios» (I, p. 134), «consejas de horneras, mentiras y falsos testimonios» (I, p. 135), «continuas reprehensiones» (I, p. 136), «opinión y voz del vulgo» (I, p. 140). Esta riqueza lexicográfica delinea el ejercicio inmisericorde del cuchicheo frente al cual sólo le resta al narrador admitir que si su padre tuvo algunos defectos no ha sido ni será el único, que todo mundo, incluso el lector, tiene cola que le pisen. Que Guzmán haya logrado disfrazar una actitud tan vehemente bajo la impostura del sermón no es su menor virtud.

La maledicencia incluso penetra en algunos elementos textuales vinculados al terreno de lo sagrado. El protagonista de la Atalaya, además de "heredar" de su padre varios aspectos (hipocresía, latencia homosexual, etc.), también recibe la práctica de rezar a toda hora, una costumbre que, por cierto, le acarreó graves suspicacias al renegado. ${ }^{27} \mathrm{El}$ pícaro, por su parte, invoca a Dios en las más variadas circunstancias,

sevillano en El coloquio de los perros venía exigida por el aspecto moral, tan involucrado en toda crítica coetánea de la picaresca. Es preciso dejar bien sentado que, aparte de constituir un contrasentido artístico, la homodiégesis guzmanesca encubre la manipulación hipócrita de la realidad. Su sermoneo representa una continua ruptura enfadosa, que puede ser vista como un intento de pasar por filosofía la murmuración maligna y misantrópica de un autor demasiado confiado en su señorío del lenguaje. [...] Cervantes pensaba a las claras que dicha clase de libros sólo podía originarse a partir de la propia experiencia inmoral y de la hipocresía literaria de sus autores. Mateo Alemán no podría menos de estremecerse en lo más profundo al leer aquello de que, vista de cerca, la vida de los murmuradores es toda vicios e insolencias» (op. cit., pp. 275-276). Recientemente M. Cavillac ha mostrado que la reflexión cervantina sobre la murmuración alemaniana se extiende más allá del Coloquio, al identificar en el personaje del malediciente Clodio del Persiles un retrato donde "se transparentan en filigrana tanto Guzmán como Alemán” («Del Guzmán de Alfarache al Persiles: Cervantes frente a Mateo Alemán (¿Por qué Clodio no merece ir a Roma?)», Criticón, 101 (2007), p.191).

26 «[...] mas la evidentemente buena, sin sombra de cosa que no lo sea, que se murmure y vitupere, eso es lo que me asombra» (I, pp. 131-132); «También es verdad que esta murmuración tuvo su causa [...]» (I, p. 132); «Es murmurado de los hombres [...]» (I, p. 138); «Ya oigo al murmurador diciendo la mala voz que tuvo $[. .] ».(\mathrm{I}, \mathrm{p} .139) ;$; [...] pues demás que son actos de afeminados maricas, dan ocasión para que dellos murmuren y se sospeche toda vileza [...]» (I, p. 140).

27 «Tenía mi padre un largo rosario entero de quince dieces, en que se enseñó a rezar [...]. Nunca se 
pero sus oraciones casi nunca son escuchadas y rara vez lo sacan de sus aprietos. Una de las primeras veces que se le oye rezar es cuando abandona Sevilla y entra en la ermita de San Lázaro con la intención de hacer una breve plegaria y resguardarse durante la noche (I, i, 3), sin embargo es echado bajo el poco piadoso argumento de que el templo está por cerrar. Otro rezo fallido acaece durante el célebre manteamiento que escenifican sus parientes romanos disfrazados de demonios (I, iii, 1). Guzmán se hace cruces, reza, invoca a Jesús mil veces, pero no hay ayuda divina que lo asista $\mathrm{y}$, por ende, asume que sus atacantes no pueden ser otra cosa más que «demonios baptizados» (I, p. 381). Como se sabe, el pícaro es azotado en galeras porque el capitán supone que ha robado un cintillo. En dos ocasiones Guzmán es torturado, pero sólo ora la primera vez: «Rezaba con el alma lo que sabía, pidiendo al cielo que aquel tormento y sangre que con los crueles azotes vertía, se juntasen con los inocentes que mi Dios por mí había derramado y me valiesen para salvarme [...]» (II, p. 516). La jaculatoria es inútil, pues días más tarde recibe otro escarmiento, al grado de creer que morirá. No es su devoción, según admite él mismo, lo que salva al galeote, sino el miedo del capitán de matarlo y tener que pagar por él al rey, o sea, una mera consideración monetaria en vistas del ahorro.

Rezar en el Guzmán es, a todas luces, una alternativa ineficaz para superar aflicciones o alcanzar buena fortuna; la incapacidad del protagonista para rezar adecuadamente podría tener su origen en su costumbre de hacer que el rezo y la murmuración compartan un mismo tono. Desde el Lazarillo el rezo en la picaresca es un acto sospechoso. Allí, el ciego recita oraciones de memoria, en un «tono bajo, reposado y muy sonable, que hacía resonar la iglesia donde rezaba» ${ }^{28}$ práctica que exhibe no una devoción genuina, sino sagacidad y codicia. Más importante aún es que Gonzalo Correas manifieste que las oraciones de ciego solían decirse como «las lecciones o sermones decorados, que van con tono igual y no parece que lo entiende el que dice». ${ }^{29}$ Es muy probable que esta invocación mecánica haya pasado del Lazarillo al Guzmán, según lo atestiguan las actitudes del padre levantisco y de su hijo. Ahora bien, el acto, que inaugura la vida nómada del pícaro y en cierto sentido enmarca su bautizo literario, ${ }^{30}$ es el rezo: «[...] para no ser conocido, no me quise valer del apellido de mi padre; púseme el Guzmán de mi madre y Alfarache de la heredad adonde tuve mi

le caía de las manos. Cada mañana oía su misa, sentadas ambas rodillas en el suelo, juntas las manos, levantadas del pecho arriba, el sombrero encima dellas» (I, p. 132).

28 Lazarillo de Tormes, ed. de Francisco Rico, Madrid, Cátedra, 1987, p. 26.

29 G. Correas, Vocabulario de refranes y frases proverbiales (1627), texte établi, annoté et présenté para L. Combet, Lyon, Institut d'études ibériques e ibéro-américaines de l'Université de Bordeaux, 1967.

30 Creo que no se ha reparado aún en el hecho importantísimo de que Guzmán jamás mencione haber sido bautizado; en un libro atiborrado de cuestiones teológicas esto parece ser grave, pues implicaría la persistencia del pecado original en el protagonista. 
principio. Con esto salí a ver mundo, peregrinando por él, encomendándome a Dios y buenas gentes, en quien hice confianza» (I, p. 162). ${ }^{31}$ «Encomendarse» es definido por Autoridades como «entregarse y resignarse en mano de otro, y fiarse de su amparo y voluntad». Podemos asumir que esta acción fue acompañada de rezos, oraciones y ciertas letanías que Guzmán habrá conocido a su corta edad, ${ }^{32}$ sin embargo no parece haberse beneficiado de esta supuesta conducta devota, pues se acumularán a granel en su biografía momentos ominosos y funestos. ¿Por qué no le sirvió el acto pío de encomendarse a Dios, de rezar una oración en su nombre solicitando apoyo para el acto más trascendental de su joven vida? Desde luego hay un cúmulo de razones, pero tal vez una se halle en el campo semántico del verbo «encomendar». Autoridades registra para el verbo de marras una curiosa acepción que debió caer en desuso, pues desaparece a partir de la versión de 1783, pero que en los tiempos de Alemán era frecuente y la emparienta peligrosamente con la murmuración, pues «encomendar» también «Se suele usar por maldecir: y no pocas veces se toma supersticiosamente por encargar y fiar al diablo ù del diablo, esperando de él que haga lo que se desea, no siendo lícito hacerlo». Esto abre la posibilidad de que el valor semántico del lexema «encomendándome a Dios y buenas gentes» se deslice hacia una variedad sacrílega, por no decir diabólica, del rezo.

«Rezar»y «murmurar» constituyen una pareja que provoca bastantes desconfianzas no sólo en el Guzmán. En el Coloquio de los perros, obra donde la murmuración también es un leitmotiv, confiesa la hechicera Cañizares: «Rezo poco y en público, murmuro mucho y en secreto», produciendo así una antinomia entre la santidad fingida y la brujería. ${ }^{33}$ Pero otro ejemplo del mismo Cervantes echa aún más luz sobre el rezo sacrílego del niño Guzmán. El episodio que refiere la decisión del futuro pícaro de abandonar su ciudad natal, armarse pícaro y autobautizarse es equivalente mutatis mutandis al momento en que un hombre es armado caballero y recibe su epíteto. Por lo tanto es de esperarse que una obra tan anti-caballeresca como el Guzmán parodie dicha escena. ${ }^{34}$ De su lado, Cervantes también parodia la ceremonia de investidura del caballero andante, pero lo hace desde los códigos internos de la novela de caballerías:

\footnotetext{
31 Por cierto, no deja de ser irónico que la madre de Guzmán sea conocida como «la comendadora» (I, p. 158), por aquello de su relación con un viejo caballero de hábito militar.

32 Encomendar el alma: «Es rogar a Dios por ella, antes de espirar uno, rezando y diciendo las letanías, preces y oraciones que la Iglesia tiene destinadas para este santo fin» (Autoridades).

33 Véase S. Pérez-Abadín Barro, «La Arcadia y otros modelos literarios del Coloquio de los perros de Cervantes: apuntes sobre magia», Nueva Revista de Filología Hispánica, 54.1 (2006), pp. 82-88.

34 La escena, a su vez, es una clara reminiscencia de la despedida de Lázaro de su madre: «En este tiempo vino a posar al mesón un ciego [...], me pidió a mi madre, y ella me encomendó a él, diciéndole cómo era hijo de un buen hombre [...]» (Lazarillo de Tormes, op. cit., p. 20).
} 
Advertido y medroso desto el castellano, trujo luego un libro donde asentaba la paja y cebada que daba a los arrieros, y con un cabo de vela que le traía un muchacho, y con las dos ya dichas doncellas, se vino adonde don Quijote estaba, al cual mandó hincar de rodillas; y, leyendo en su manual, como que decía alguna devota oración, en mitad de la leyenda alzó la mano y diole sobre el cuello un buen golpe, y tras él, con su mesma espada, un gentil espaldarazo, siempre murmurando entre dientes, como que rezaba. ${ }^{35}$

El párrafo muestra que, a oídos de Cervantes, existió bajo ciertas circunstancias una correspondencia entre «rezar», «murmurar»y «maldecir», tal cual también prevaleció en la mente de Mateo Alemán cuando hizo encomendarse a su pícaro, quien, en realidad, podría más bien estar maldiciendo su suerte. La asociación rezarmurmurar-maldecir resulta aún más obvia en un episodio de la vida adulta del galeote. Antes de contraer nupcias por segunda ocasión, Guzmán relata sus continuos desencuentros con las amas, a quienes siempre termina por despedir: «Cuando los vecinos vieron que había tenido en seis días tres mujeres y que cada una, cuando salía, iba rezando y murmurando de mí, levantóse una mala voz, pusiéronme cien faltas, y tanto, que más de veinte días me fui a comer al bodegón, que ninguna mujer quería venir a mi casa [...]» (II, p. 420). Las mujeres que salen de casa de Guzmán rezan y murmuran colectivamente en una acción que termina por convertir las plegarias en maldiciones, corroborando la tendencia establecida por aquella primera súplica de Guzmán al alejarse de su patria chica.

Evocar el arte de mal decir de Mateo Alemán sin hacer referencia a una de las cuestiones que más ha ocupado a la crítica se torna ineludible. A mi modo de ver, la cuestión de si estamos ante una conversión sincera o no de parte del protagonista vale la pena ser inquirida desde el punto de vista de la murmuración.

En la cárcel de Sevilla donde aguarda su juicio y sentencia, Guzmán conoce a un delincuente llamado Soto, con quien establece estrechos lazos con tintes homosexuales. Tras su condena a servir en galeras de por vida, el famoso pícaro y Soto arriban al puerto de embarque. Soto, sin embargo, muestra su faceta traidora durante el trayecto, después de que Guzmán le pide su cooperación para esconder un pequeño hurto que consumó en una venta. Cuando nuestro pícaro le solicita el botín de regreso, su supuesto amigo se hace el desentendido. Ante la inesperada situación Guzmán se alía con el comisario, prometiéndole la mitad del latrocinio. La atractiva propuesta seduce al funcionario, quien no duda en someter al castigo de los cordeles a Soto hasta que

\footnotetext{
35 Miguel de Cervantes, op. cit., p. 60. G. Illades analiza este episodio a partir de la identificación entre murmurar y rezar: «El ventero no lee, finge hacerlo, pues el manual, también fingido, no es de caballería, sino libro de cuentas de paja y cebada. Lo que hace es murmurar entre dientes, como murmuraría si rezara. El aparte del ventero, entreoído por don Quijote, deviene rito apócrifo por medio del cual un loco resulta armado caballero a través de una actio común al rezo y a la maledicencia» («Sátira, prédica y murmuración: genealogía de una contienda por la voz en el Quijote de 1605», op. cit., p. 175).
} 
revela haber guardado el hurto en los interiores del lechoncillo muerto que llevaba consigo. A raíz de este incidente se origina la gran enemistad entre Soto y Guzmán, que influirá decisivamente en el desenlace de la obra.

Quiso la mala suerte del protagonista que cuando se llevó a cabo el repartimiento Soto y él fueron asignados al mismo navío. En estado constante de alerta por temer una felonía, Guzmán paulatinamente se granjea la confianza del cómitre, al grado de convertirse en su sirviente predilecto, lo que inaugura una temporada de bonanza para el galeote. Pero su fortuna muda cuando al barco llega un pariente del capitán, quien ve sustraídos varios eslabones de una cadena de oro. Con la intención de evitar futuras enajenaciones, el capitán le sugiere tomar bajo su servicio a un forzado. Al escuchar las virtudes de Guzmán, entre las que destacan ser «entretenedor y gracioso» (II, pp. 509-510), el pariente decide incorporarlo a su servidumbre. Se advierte una vez más que la labia es, tal vez, su mayor atributo, ${ }^{36}$ pues la afición de su nuevo amo por escucharlo es tan adictiva que deja de platicar con el resto de sus acompañantes para entablar prolongadas conversaciones con él.

No obstante, la mala fama que ha hostigado a Guzmán desde el momento de su nacimiento tampoco lo deja en la galera en paz, pues Soto se hace a la tarea de difamarlo hasta que las reiterantes murmuraciones llegan a oídos de su amo, truncando así la incipiente relación de confianza. ${ }^{37}$ La situación se torna insostenible cuando Soto persuade a un criado del pariente del capitán para que sustraiga un «trincheo» ${ }^{38}$ de la mesa de su amo y lo esconda entre las pertenencias de galeoteescritor. Posteriormente, el orquestador del maquiavélico plan se encarga de hacer correr el rumor de que Guzmán ha hurtado esa pieza de la vajilla. Éste, por supuesto, niega las acusaciones, pero el cómplice de Soto sugiere buscar entre sus propiedades donde, en efecto, encuentran el hurto. Gracias a la oportuna intervención de su amo el pícaro libra un severo castigo, bajo la advertencia de ser disciplinado ante una nueva falta.

36 Lo mismo había sucedido anteriormente con el cómitre: «Cayóle al cómitre tan en gracia lo bien que le truje acomodado el cuento, que me hizo mudar luego de banco, pasándome a su servicio con el cargo de su ropa y mesa, por haberme siempre hallado igual a todo su deseo» (II, p. 501).

37 «Pero hacía [mi amo] en esto lo que los destiladores: alambicábame y, cuando había sacado la sustancia que deseaba, retirábase o, por mejor decir, se recelaba de mí, que no las tenía todas cabales, por la mala voz con que Soto me publicaba por malo» (II, p. 511). Ya anteriormente, Guzmán ha aludido al constante mal decir de Soto en la galera: «Deseábale todo bien [a Soto] y hacíame cuanto mal podía, desacreditándome, diciendo cosas y embelecos del tiempo que fuemos presos y él supo míos en la prisión» (II, p. 510).

${ }^{38}$ Trincheo: «plato pequeño que sirve para trinchar la comida, o para servir las piezas ya trinchadas» (Autoridades). 
Poco tiempo después, Guzmán vuelve a estar implicado en un aparente robo, relacionado con el cintillo de un sombrero. Según previa resolución, el galeote es azotado sin misericordia y para su convalecencia es enviado de nueva cuenta a la corulla, donde el cómitre lo somete a un severo trato. Al pícaro se le asigna el banco final hacia la proa y, entre sus múltiples tareas, se le encomienda recoger sobras de maromas que utilizan como material higiénico los galeotes, soldados y marineros.

En esos días su archienemigo concibe un plan para amotinarse, pero considerando la posición de Guzmán en la corulla, así como sus otras actividades, Soto es consciente que su plan fracasará si no lo invita a unírsele. La víspera del complot, Guzmán se inclina por denunciar a los conspiradores. Durante la madrugada, cuando un soldado acude a defecar cerca del lugar donde pernocta, Guzmán, al proveerlo de material para su limpieza, le susurra al oído: «Señor soldado, dígale Vuestra Merced al capitán que le va la vida y la honra en oírme dos palabras del servicio de Su Majestad. Que me mande llevar a la popa» (II, p. 521). Estas palabras tan definitivas para los acontecimientos finales del libro son una delación hablada «entre dientes». Atento a que los otros galeotes no lo escuchen, se sobreentiende que Guzmán se acerca al oído del militar para persuadirlo de que lo lleve ante el capitán. Para algunos estudiosos del Pícaro, este capítulo confirma la conversión del protagonista, sin embargo, no deja de extrañar que el acto final del pseudoautobiógrafo sea uno que, desde el punto de vista de la murmuración, era asociado en aquella época con el demonio. Entre los sinónimos que consigna Covarrubias del vocablo «diablo» se encuentran acusador, calumniador, engañador, soplón y malsín, ratificando al demonio como el gran murmurador de todos los tiempos. ¿Acaso quiso Alemán que sus lectores reconocieran en Guzmán un soplón que susurra, en voz baja, su petición al soldado para, posteriormente, dar rienda suelta a su murmuración frente al capitán? De ser éste el caso, la imagen de Guzmán y del demonio se funden en una. ${ }^{39}$ En consecuencia, la conclusión de la obra se torna más siniestra de lo que una supuesta conversión del galeote sugiere y termina por remitirnos al subtítulo de la Segunda Parte. Si se acepta en la figura de Guzmán al más grande murmurador de principios del xVII y que en la mentalidad española de la época predominaba la asociación semántica entre murmurador y diablo, entonces el pícaro no sermonea desde el púlpito, sino murmura desde un sitio donde la malicia hace su hogar, que no puede ser otro más que la atalaya: «[...] un enemigo [...] es una atalaya que con cien ojos vela, como el dragón, sobre la torre de su malicia, para juzgar desde muy lejos nuestras obras [...]. ¿Quieres conocer quién es? Mírale el nombre, que

\footnotetext{
39 N. von Prellwitz ve en Soto a otro calumniador, asociado con el demonio: «Asimismo corresponde a la característica de diabolos maldiciente el hecho de que Soto acuse a Guzmán por medio de una calumnia» («Presencias luciferinas en el Guzmán de Alfarache», en I. Arellano et alii (eds.), Studia Aurea. Actas del III congreso de la AISO, vol. 3, Toulouse, GRISO-LEMSO, 1996, p. 420). Lo que nuestro análisis revela es que Guzmán resultó mayor murmurador que Soto, o sea, más diabólico.
} 
es el mismo del demonio, enemigo nuestro, y ambos son una misma cosa» (I, p. 308). La equivalencia que fijamos en un inicio deviene más compleja y extensa: atalayapredicador-ladrón-murmurador-diablo. De esta forma, el discurso de Guzmán no se limita a ser una pseudohomilía, sino reclama para sí el calificativo de antisermón de tonos blasfemos. ${ }^{40}$

Según se colige, lo que define la actitud del narrador es la reacción ante las habladurías, pues, aunque no quiera, se ve obligado a prestar oídos a las murmuraciones y a cederles espacio, voluntaria o involuntariamente, en su propio discurso. ${ }^{41}$ Es de destacar que Guzmán procure anular el coro de chismes, rumores e insidias contramurmurando, posibilitando así un espacio que se hace tentador pensar como liberador de pulsiones reprimidas.

El Guzmán de Alfarache, entonces, se hace eco de una actio engendrada en La Celestina para dar voz al descontento de ciertas clases marginadas, sólo que bajo la pluma de Alemán el arte de mal decir sube de tono en el momento en que a través del pícaro la frustración social se apodera del púlpito. ${ }^{42}$ ¿Será que éste es el pecado que jamás le perdonaron sus contemporáneos al sevillano? Hasta ahora se ha especulado que su mayor paso en falso en el terreno de las letras fue ignorar la convención del anonimato para un género tan explosivo, cuya paternidad se hacía imposible reclamar $\mathrm{y}$, mucho menos, invitaba a incluir el retrato del autor entre sus páginas. Esto, aunado a su escandalosa vida y su calidad de outsider en el mundo literario, le acarreó a Alemán envidias y difamaciones, no siendo la menor la que le asesta el médico Francisco

40 La atalaya es, por cierto, el sitio, como ya se ha apuntado, desde donde ciertas aves de rapiña cazan a sus víctimas. Nótese que en el Guzmán se describe a la murmuración como un ave: «Es el ave de más ligero vuelo, que más presto se abalanza y más daño hace» (I, p. 224). M. Cavillac llama a precaución a quienes juzgan con ligereza a Guzmán como un delator infame, ya que «el galeote podía ampararse al respecto en la casuística contemporánea proclive a admitir (en particular con el Padre Rivadeneyra) que "cuando la necesidad o utilidad grande lo pide", "la disimulación" e incluso "la mentira" eran lícitas: en tales casos ("especialmente en tiempo de guerra") -arguye Rivadeneyra- "esto no es mentir, sino hacer las cosas con prudencia para bien de la república"» («Política y poética en el Guzmán de Alfarache», en I. Arellano et alii (eds.), Studia Aurea. Actas del III Congreso de la AISO, vol. 3, Toulouse, GRISO-LEMSO, 1996, p. 93).

${ }^{41}$ «Díjome luego lo que dije que le habían dicho y lo que le había pasado sobre mesa [...]» (II, p. 132).

42 «En cambio, si contemplamos la literatura anterior y posterior a la picaresca, fácil es reconocer aquella locuacidad crítica en los cuadros de costumbres y fantasías morales que de la picaresca derivan [...] y en algunos de sus más probables precursores, conocidos o no de los autores picariles: Celestina peroraba y murmuraba, Trotaconventos era llamada por su tutelado "picaza parladera", el Momo -tan citado por la pícara Justina- miraba para encontrarlo todo mal y hablaba para decir mal de todo [...]», (G. Sobejano, op. cit., p. 468). Por otro lado, Alemán pertenece a un grupo de reformadores sociales y económicos (Alonso de Barros, Hernando de Soto, Cristóbal Pérez de Herrera) que poco o nada tienen que ver con los bajos fondos $\mathrm{y}$, más bien, identificamos entre los intelectuales de la burguesía conversa; véase $\mathrm{F}$. Márquez Villanueva, «Sobre el lanzamiento y recepción del Guzmán de Alfarache», Bulletin Hispanique, 92 (1990), pp. 549-577. Tal afán reformador también implica un tono específico que valdría mucho la pena estudiar. 
López de Úbeda en La pícara Justina, donde lo acusa de ruin, amancebado, tahúr e, incluso, sodomita. ${ }^{43} \mathrm{Al}$ malediciente vulgo del prólogo a la Primera Parte del Guzmán se sumaba ahora la voz de un converso y médico como él. El problema no es nada más que se pensara que un libro atiborrado de murmuraciones como el suyo sólo podía ser engendrado por un hombre ruin, vicioso y misántropo. Más bien, Mateo Alemán sacó a relucir uno de los grandes pecados de su tiempo. En su Tractado muy provechoso contra el común é muy continuo pecado que es detraher ó murmurar y decir mal de alguno en su absencia, fray Hernando de Talavera concede que es imposible ayudar al murmurador $\mathrm{y}$, por consiguiente, procura salvar al oyente, amonestando que peca mortalmente quien disfruta oír las maledicencias. ${ }^{44}$ Ahora bien, el vertiginoso éxito editorial de la Primera Parte del Guzmán $n^{45}$ exhibe una sociedad española en pecado mortal, que, por un lado, se deleita en murmurar y, por otro, se regodea escuchando vidas ajenas.

Sabido es que Alemán huyó a las Indias a raíz de los ataques de Úbeda, entre otras cuestiones. En México publica en 1609 su Ortografía castellana y para 1613 se extingue su voz con los Sucesos de don fray García Guerra. Bien vista, dicha obra no es un estricto panegírico de su malogrado bienhechor, sino un ejercicio de «contramurmuración». ${ }^{46}$ Alemán defiende al arzobispo-virrey de las habladurías que sostienen que su muerte se debió al festejo de una corrida de toros en Viernes Santo y por no consentirles a unas monjas carmelitas la fundación de un convento. Por añadidura, el sevillano desautoriza el tratamiento médico que se dispensó a su benefactor y califica a los galenos de incompetentes, además de dirigir sus dardos contra los ingratos aduladores que a la muerte del virrey lo sepultaron en el olvido.

Vistas así las cosas, la obra de Mateo Alemán se perfila como hija de la murmuración, a la que jamás pudo despistar ni siquiera con un viaje trasatlántico. En

43 Debemos a F Márquez Villanueva («La identidad de Perlícaro», en Homenaje a José Manuel Blecua ofrecido por sus discípulos, colegas y amigos, Madrid, Gredos, 1984, pp. 423-432) la identificación del personaje de Perlícaro en La Pícara Justina con Mateo Alemán.

${ }_{44}$ Citado por G. Illades, «Sátira, prédica y murmuración: genealogía de una contienda por la voz en el Quijote de 1605», op. cit., p. 172.

45 Véase J. L. Laurenti y J. Siracusa, «Ensayo de una bibliografía del sevillano Mateo Alemán (1547¿1614?)», Archivo Hispalense, 139-140 (1966), pp. 179-216. La Primera Parte tuvo entre 1599 y 160426 ediciones, algo sin precedentes para un libro de sus características.

46 «Los Sucesos son un noble testimonio de justicia y gratitud en defensa de fray García Guerra, frente a las supersticiosas interpretaciones que los accidentes del gobierno y la repentina muerte de este personaje habían suscitado» (Navarro Tomás, «La ortografía de Mateo Alemán», en Ortografía castellana, ed. de J. Rojas Garcidueñas, México, El Colegio de México, 1950, p. xv). «La obra es, pues, toda ella un ejercicio de contra-murmuración en que el arzobispo-virrey y el judeoconverso sevillano hacen causa común» (F. Márquez Villanueva, «El canto de cisne de Mateo Alemán: los "Sucesos de d. frai García Guerra" (1613)», en Inquisición y conversos. III curso de cultura hispano-judía y serfardí de la Universida de Castilla-La Mancha, Madrid, Asociación de Amigos del Museo Sefardí / Caja de Castilla-La Mancha, 1994, p. 258). 
la primera dedicatoria que firmó, el sevillano se dirige a don Francisco de Rojas para protegerse de los hombres malintencionados:

A éstos, pues, de cuyos lazos engañosos, como de la muerte, ninguno está seguro, siempre les tuve un miedo particular, mayor que a los nocivos y fieros animales, y más en esta ocasión, por habérsela dado y campo franco en que puedan sembrar su veneno, calumniándome cuando menos, de temerario, atrevido [...] (I, p. 107).

Catorce años más tarde, en la primera página de los Sucesos de don fray García Guerra, Alemán expresa que su propósito es «desenterrar» las virtudes del prelado y dedicar dicha obra a don Antonio de Salazar «para que cuando la murmuración ejercitare contra mí su oficio, pueda tener seguridad que no le será posible morder en la legalidad con que va escrito».47 Asimismo, al término de la «Oración fúnebre» en voz de la Ciudad de México solloza Alemán, quien reconoce en la defunción del arzobispovirrey un ciclo de seguridad clausurado: «Toda la noche di voces, que me tienen la boca horadada y no me dieron socorro. Velan y no duermen los que mis carnes despedazan y entre su multitud están rotas mis vestiduras». ${ }^{48}$ Tres ejemplos ofrecen un mismo número de verbos pertenecientes al léxico del mal decir: «desenterrar», «morder»y «despedazar». Medio mundo lejos de su tierra, Alemán terminó por afianzar su visión nosológica de la humanidad desplegada en su obra maestra, ratificando una última vez que todos los hombres están irremediablemente enfermos: la murmuración no es problema exclusivo de España, sino atañe a todo el género humano, como escribe Cervantes, en el párrafo que más lo acerca al pensamiento de su genial contemporáneo:

[...] por lo cual vuelvo a decir lo que otra vez he dicho [sostiene Berganza]: que el hacer y decir mal lo heredamos de nuestros primeros padres y lo mamamos en la leche. Vése claro en que apenas ha sacado el niño el brazo de las fajas cuando levanta la mano con muestras de querer vengarse de quien, a su parecer, le ofende; y casi la primera palabra articulada que habla es llamar puta a su ama o a su madre. ${ }^{49}$

Desconozco cuál habría sido el gesto de nuestro atribulado sevillano de haber leído en tierras mexicanas estas palabras, pero sospecho que, como pocos, sabría entonarlas «entre dientes».

\footnotetext{
47 Sucesos de D. Frai García Guera, arzobispo de México, ed. A. H. Bushee, Revue Hispanique, 25 (1911), p. 379; modernizo la ortografía.

48 Ibidem, p. 419.

49 M. de Cervantes, «Coloquio de los perros», en Novelas ejemplares, vol. 2, ed. de J. B. Avalle-Arce, Madrid, Castalia, 2001, p. 262-263.
} 


\section{Bibliografía}

Alemán, M., Guzmán de Alfarache, ed. de J. M. Mico, 2 tomos, Madrid, Cátedra, 1992 y 1994.

---------, Ortografía Castellana, ed. de J. Rojas Garcidueñas, estudio preliminar Tomás Navarro, México, El Colegio de México, 1950.

--------, San Antonio de Padua, Sevilla, Clemente Hidalgo, 1604.

- Sucesos de D. Frai García Guera, arzobispo de Méjico, ed. de A. H. Bushee, Revue Hispanique, 25 (1911), pp. 359-457.

Arcipreste de HitA, Libro de buen amor, ed. de A. Blecua, Madrid, Cátedra, 1998.

Arias, J., Guzmán de Alfarache: The Unrepentant Narrator, Londres, Tamesis, 1977.

Cascardi, A. J., «The Rethoric of Defense in the Guzmán de Alfarache», Neophilologus, 63 (1979), pp. 380-399.

Cavillac, M., «Política y poética en el Guzmán de Alfarache», en I. Arellano et alii (eds.) Studia Aurea. Actas del III Congreso de la AISO, vol. 3, Toulouse, GRISO-LEMSO, 1996, pp. 89-95.

--------, «El diálogo del narrador con el narratario en el Guzmán de Alfarache de Mateo Alemán», Criticón, 81-82 (2001), pp. 317-330.

---------, «Del Guzmán de Alfarache al Persiles: Cervantes frente a Mateo Alemán (¿Por qué Clodio no merece ir a Roma?)», Criticón, 101 (2007), pp. 177-198.

Cervantes, M. de, «Coloquio de los perros», Novelas ejemplares, 2 tomos, ed. de J. B. Avalle-Arce, Madrid, Castalia, 2001, pp. 241-322.

--------, Don Quijote de la Mancha, edición dirigida por F. Rico, Barcelona, Crítica, 1998.

Chauchadis, C., «Virtudes y pecados de la lengua: Sebastián de Covarrubias y Martín de Azpilcueta», Criticón, 92 (2004), pp. 39-45.

Correas, G., Vocabulario de refranes y frases proverbiales (1627), texte établi, annoté et présenté par L. Combet, Lyon, Institut d'études ibériques e ibéroaméricaines de l'Université de Bordeaux, 1967.

Covarrubias, S. de, Tesoro de la lengua castellana o española, ed. de M. de Riquer, Barcelona, Alta Fulla, 2003.

CROs, E., Protée et le gueux. Recherches sur les origines et la nature du récit picaresque dans «Guzmán de Alfarache», París, Didier, 1967.

--------, Mateo Alemán. Introducción a su vida y obra. Salamanca, Anaya, 1971.

Diccionario de Autoridades, 3 vols., ed. facsímil, Madrid, Gredos, 1990.

FRENK, M., Entre la voz y el silencio. La lectura en tiempos de Cervantes, México, Fondo de Cultura Económica, 2005.

IllADES, G., «Observaciones sobre la actio del lector. (De La Celestina a la sátira anónima novohispana)», Escritos, Revista del Centro de Ciencias del Lenguaje, 26 (2002), pp. 13-35. 
----------, «Arte y pecado de mal decir en el Quijote de 1605», en G. Illades y J. Iffland (eds.), El «Quijote» desde América, México, Benemérita Universidad Autónoma de Puebla-El Colegio de México, 2006, pp. 163-182.

, «Sátira, prédica y murmuración: genealogía de una contienda por la voz en el Quijote de 1605», Cervantes, 27.1 (2007), pp. 161-178.

Laurenti, J. L. y J. Siracusa, «Ensayo de una bibliografía del sevillano Mateo Alemán (1547-¿1614?)», Archivo Hispalense, 139-140 (1966), pp. 179-216.

Lazarillo de Tormes, ed. de F. Rico, Madrid, Cátedra, 1987.

Libro de Alexandre, ed. de J. Cañas, Madrid, Cátedra, 1995.

López Grigera, L., «La invención del Guzmán de Alfarache (1599) entre Poética y Retórica», en P. M. Piñero Ramírez (ed.), Atalayas del «Guzmán de Alfarache», Seminario internacional sobre Mateo Alemán. IV Centenario de la publicación de Guzmán de Alfarache (1599-1999), Sevilla, Universidad de Sevilla, 2002, pp. 255-270.

Márquez Villanueva, F., «La identidad de Perlícaro», en Homenaje a José Manuel Blecua ofrecido por sus discípulos, colegas y amigos, Madrid, Gredos, 1984, pp. 423-432.

----------, «Sobre el lanzamiento y recepción del Guzmán de Alfarache», Bulletin Hispanique, 92, 1990, pp. 549-577.

---------, «El canto de cisne de Mateo Alemán: los “Sucesos de d. frai García Guerra” (1613)», en Inquisición y conversos. III curso de cultura hispano-judía y serfardí de la Universida de Castilla-La Mancha, Madrid, Asociación de Amigos del Museo Sefardí / Caja de Castilla-La Mancha, 1994, pp. 240-260.

---------, «La interacción Alemán-Cervantes», en Trabajos y días cervantinos, Alcalá de Henares, Centro de Estudios Cervantinos, 1995, pp. 241-297.

NAvarro Tomás, T., «La ortografía de Mateo Alemán», en Ortografía castellana, ed. de J. Rojas Garcidueñas, México, El Colegio de México, pp. xiii-xxxix.

Pérez-Abadín Barro, S., «La Arcadia y otros modelos literarios del Coloquio de los perros de Cervantes: apuntes sobre magia», Nueva Revista de Filología Hispánica, 54.1 (2006), pp. 57-101.

Peale, G. C., «Guzmán de Alfarache como discurso oral», Journal of Hispanic Philology, 4 (1979), pp. 25-57.

Prellwitz, N. von, Il discorso bifronte di Guzmán de Alfarache, Roma, Bagatto Libri, 1992. -, «Presencias luciferinas en el Guzmán de Alfarache», en I. Arellano et alii (eds.), Studia Aurea. Actas del III Congreso de la AISO, vol. 3, Toulouse, GRISO-LEMSO, 1996, pp. 421-424.

RAвAtÉ, Ph. «El discurso agustiniano de Mateo Alemán: de la herencia adánica a la “reformación” individual en el Guzmán de Alfarache», Criticón, 107 (2009), pp. 105-135. 


\section{Francisco Ramírez Santacruz}

RojAs, F. de, Comedia o Tragicomedia de Calisto y Melibea, ed. de P. E. Russell, Madrid, Castalia, 1991.

Sмiтн, H. D., «The Pícaro Turns Preacher: Guzmán de Alfarache's Missed Vocation», Forum for Modern Language Studies, 14 (1978), pp. 387-397.

Sobejano, G., «Un perfil de la picaresca: el pícaro hablador», en Studia Hispanica in Honorem R. Lapesa III, Madrid, Gredos, 1972, pp.467-485. 